\title{
Use of historical sources in a study of the 1895 floods on the Danube River and its tributaries
}

\author{
Marián MeloA, Pavla Pekárová ${ }^{B}$, Pavol Miklánek ${ }^{B}$, Katarína MelováC, Cyntia DujsíkováD \\ Received: June 15, 2014 | Revised: September 28, 2014 | Accepted: November 30, 2014
}

\begin{abstract}
Hydrological data series that are measured on the Danube River are temporally limited. Instrumental flow data can be prolonged by documentary data from historical sources in archives. This paper deals with knowledge gained by studies of historical materials regarding the 1895 catastrophic floods on the Danube River and its tributaries as reflected in the contemporary local press and also in studies of other historical records (flood marks, chronicles, books and photos). Records from the newspapers (Wiener Zeitung, Preßburger Zeitung, The New York Times and Komáromi Lapok) and other analysed sources show the relatively large territorial impact of the floods in March and April 1895, which affected not only the Danube and its tributaries, but also some neighboring basins. Catastrophic consequences of the flood were especially reported from the lower parts of the Danube River (from its confluence with the Drava River up to the mouth of the Black Sea) and the tributaries of the Tisza and Sava rivers. In 1895, the second highest flood after the 2006 flood on the Lower Danube was observed since 1841.
\end{abstract}

Key words: Flood, the Danube, archives, newspapers, flood marks

\section{Introduction}

Floods belong to the extreme natural phenomena which occur in the Danube basin. Catastrophic floods on the Upper Danube (from the source of the Danube to the Bratislava gauge), the Central Danube, and the Lower Danube (from the Orsova gauge to the river outlet), usually do not simultaneously occur (Pekárová, et al, 2012). On the Upper Danube from the town of Passau, the highest floods during the observation period occurred in the years 1862, 1897, 1899, 1954, 2002, and 2013. On the Lower Danube they occurred in the years 1897, 1940, 1942, 1970, 1980, 1981, and 2014. In the years 1897, 1965, and 2006, floods struck the whole Danube basin. While in the Upper Danube, the highest floods originate from regional heavy rainfall events in the summer (flood durations of 10-20 days), over the Central and Lower Danube, they are mostly caused by extensive snowmelts in combination with rainfalls (flood durations of 1-3 months).
The hydrological data series measured on the Danube River are limited. In Austria, water-level measurements have been available in Vienna-Tabor since 1 January 1784 and have been published in the Wiener Zeitung newspaper until January 1785 . Later on, regular water-level observations at the Franz Bridge of the Vienna Canal were published in the Wiener Zeitung from 1 May 1811. Observations of the water levels in the River Danube have been undertaken at Linz since 1821. In Hungary, readings of the gauge at Buda have been published in a newspaper from 1 May 1814 onwards (Brázdil, et al., 2012).

The water gauging station in Bratislava was established in the $18^{\text {th }}$ century. Systematic observations of water levels began in 1823, but continuous water level data, as well as daily discharges, have been collected since 1876. This is the second longest time series of observed daily discharges; the first was from the Danube

\footnotetext{
A Comenius University, Faculty of Mathematics, Physics and Informatics, Mlynská dolina, 84248 Bratislava, Slovakia; melo@fmph.uniba.sk

B Institute of Hydrology SAS, Račianska 75, 83102 Bratislava, Slovakia; pekarova@uh.savba.sk, miklanek@uh.savba.sk

C Slovak Hydrometeorological Institute, Jeséniova 17, 83315 Bratislava, Slovakia; katarina.melova@shmu.sk

D Comenius University, Faculty of Natural Sciences, Mlynská dolina, 84215 Bratislava, Slovakia; cydney@azet.sk
} 
at the Turnu Severin (today, the Orsova) station. Figure 1a depicts the maximum annual discharges from the Orsova station. In 1895, the second highest flood after the 2006 flood on the Lower Danube was observed.

Instrumental data can be complemented by documentary data from historical sources in different archives (Bel, 1735; Neweklowsky, 1955; Kresser, 1957; Horváthová, 2003; Rohr, 2005; Brázdil, Kundzewitz, 2006; Kiss, 2009; Przybylak, et al., 2010; Kiss, 2011; Pišút, 2011; Stankoviansky, Pišút, 2011; Brázdil, et al., 2012; Elleder, et al, 2013; Melo, Bernáthová, 2013; Pekárová, et al., 2013). Most of the information presented about historical floods in the Upper Danube region has its origin in flood marks, newspaper articles, chronicles, official letters, books, maps and photos. Flood marks contain a brief description of a flooding event with an indication of the peak flood water level. In cities located along the Upper Danube (e.g., Passau, Linz, Mauthausen, Grain, Ybbs, Melk, Krems, and Hainburg an der Donau) more flood marks of historic floods can be found, even since 1501. According to Pekárová, et al. (2013), about ten historically catastrophic floods on the Danube at Bratislava from 1501 to 1876 (Figure 1b) are known. From a long-term point of view, the Danube discharges at the Bratislava station have been constant (Pekárová, et al., 2008; Blaškovičová, et al., 2013; Marušiak, Pekár, 2014).

Flood marks on the Danube downstream from Bratislava are not so frequent. In newspapers, chronicles and some books, the courses, causes and impacts of various floods are described. Kiss (2011) provided knowledge of floods in medieval Hungary based on archival sources; Munzar, Ondráček (2010) have stud- ied floods in Central Europe in July 1897; and Elleder (2010) has analysed floods from 1784 for the Vltava River in Prague.

The aim of this paper is to summarize information on the 1895 Danube floods based upon studies of the historical records (flood marks, newspapers, chronicles, books and photos) and to impart knowledge about the progress of this flooding on the Danube River and some of its tributaries.

\section{Methods and data}

Our analyses are based on mapping flood marks, information from newspapers, local chronicles, books and contemporary photos. The newspaper records originated in the following contemporary local and international press: Wiener Zeitung, Preßburger Zeitung, the New York Times, and the Komáromi Lapok in the period from late February till the end of April 1895. The basis of this analysis is represented by the newspapers Wiener Zeitung (Figure 2) and Preßburger Zeitung (Figure 3). Since both of these daily newspapers were issued in the morning (Preßburger Zeitung - Morgenblatt; Wiener Zeitung) as well as the evening (Preßburger Zeitung - Abendblatt; Wiener Abendpost - Beilage zur Wiener Zeitung), we will use the abbreviations PZ and WZ further in the text for the morning editions of these newspapers and PA and WA for the evening editions of the newspapers studied. These newspapers are available at the Austrian National Library (Österreichische Nationalbibliothek) in Vienna. The weekly newspaper Komáromi Lapok is available at the Library of the Danube Region Museum in Komárno and the New York

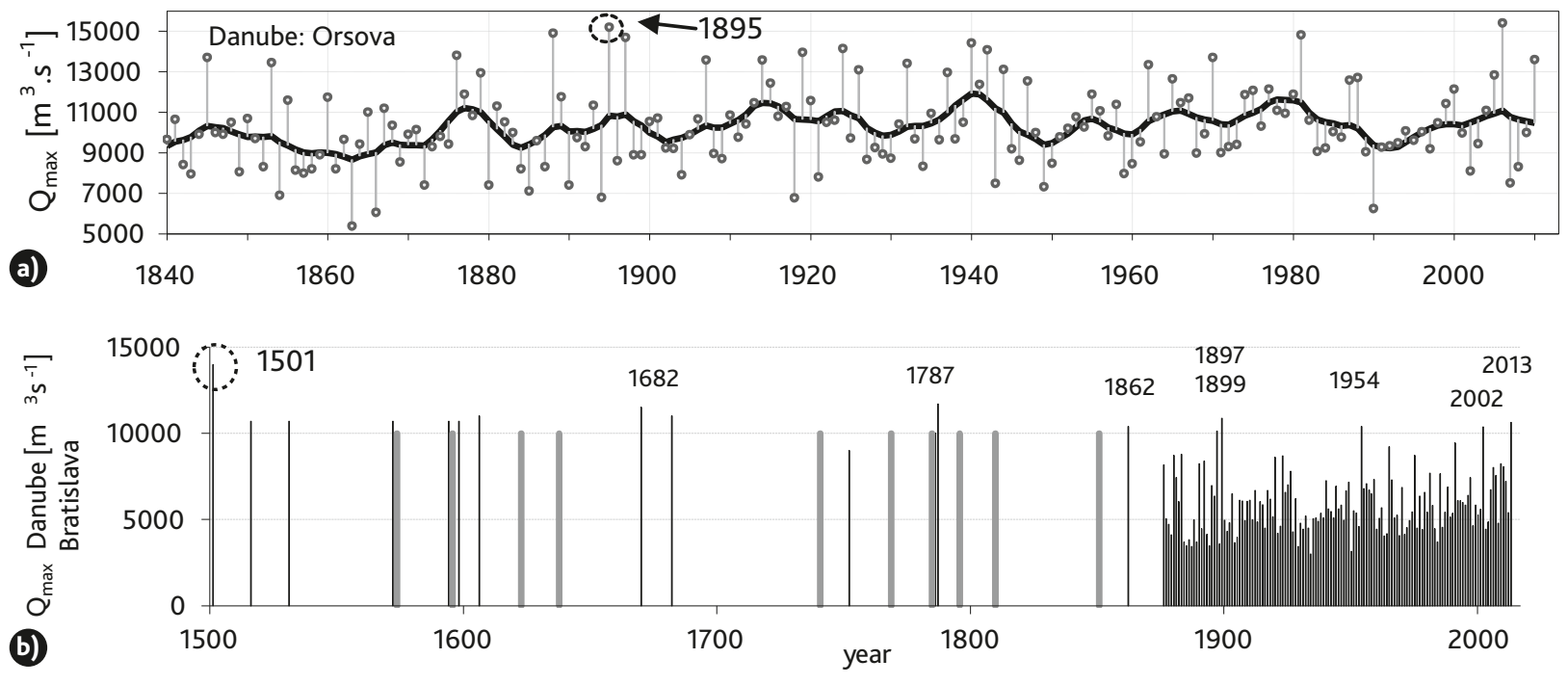

Figure 1.

a) Annual maximum discharge series Qmax (points), differences in 7-year moving averages (bolt line), the Danube at Orsova, 1840-2010.

b) Historic Danube floods at Bratislava from 1500 to 1876 (dark columns - summer floods, light columns - winter floods); since 1876 - the observed annual peaks Qmax. In 1501, the discharge was estimated up to $14000 \mathrm{~m}^{3} \mathrm{~s}^{-1}$. 


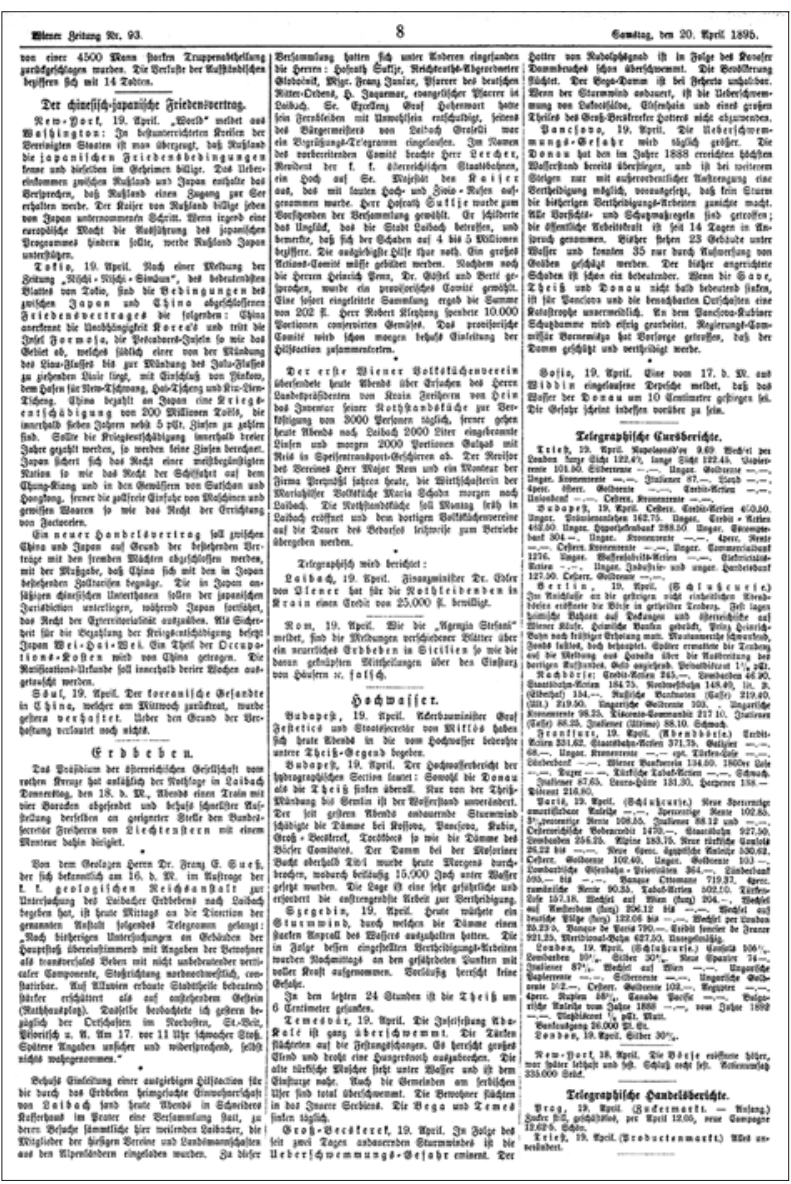

Figure 2. Report on the 1895 Danube flood in the newspaper Wiener Zeitung, No. 93, 20 April 1895: the report begins in the middle ("Hochwasser"), and continues on the right. (figure taken from the archives of the Austrian National Library in Vienna, Austria)

Times from the archives on the website of that newspaper (http://www.nytimes.com/). The photographs originate in the archives of the Danube Museum in Esztergom (Hungary) and in the archives of a private collection on the website: http://orsova.xhost.ro/.

We used the mean daily discharge data (as well as the maximum annual discharge) from the database of the "Flood regime of rivers in the Danube basin" project from two stations: Danube: Bratislava and Danube: Turnu-Severin (Orsova). In Figure 4 there is the mean daily discharge in the selected stations in 1895. In 1895,

\section{Preßburger Beitung.}

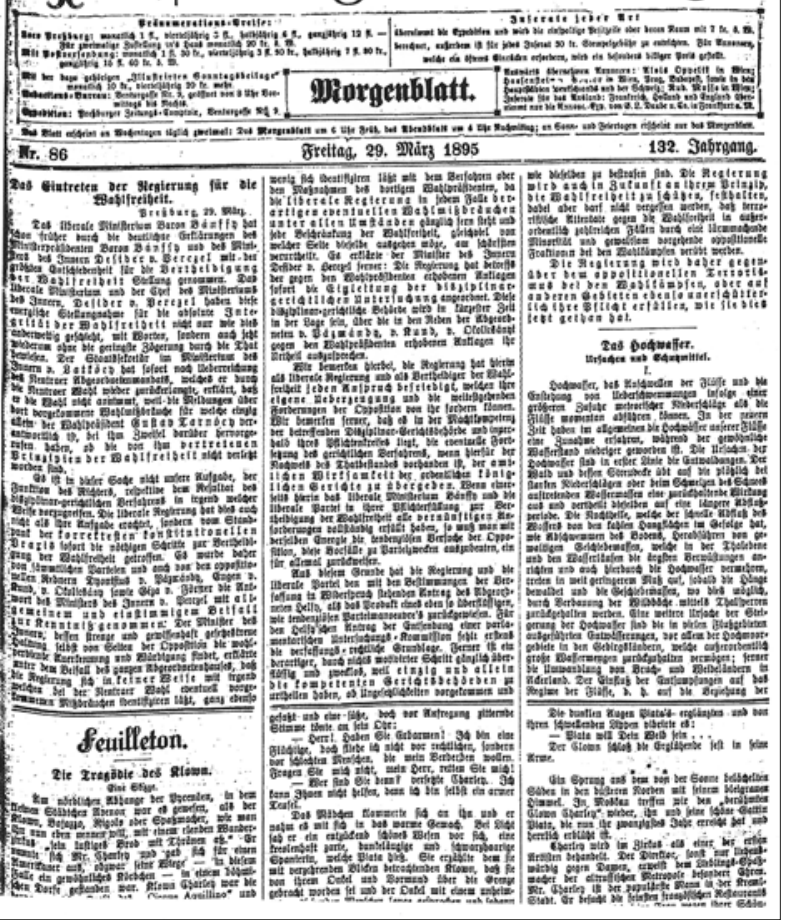

Figure 3. The front page of the Preßburger Zeitung

newspaper, 29 March 1895. (figure taken from the archives of the Austrian National Library in Vienna, Austria)

the flood wave at the Bratislava station culminated on 31 March 1895 with a discharge of $6979 \mathrm{~m}^{3} \mathrm{~s}^{-1}$. At Orsova, the flood wave in 1895 culminated on 14-18 April (about 16 days later than at Bratislava) with a discharge of $15200 \mathrm{~m}^{3} \mathrm{~s}^{-1}$.

\section{Flood marks}

After the Danube flood of 1895, six flood marks remained on historical buildings in towns located near the river (three in Slovakia: Bratislava, Komárno and Iža; three in Hungary: Komárom (Figure 5), Szőny (Figure 6) and Szigetmonostor). In all of these cases the maximum flood water level is expressed by marks delineated on churches. They contain the same brief descriptions of the flooding events in Hungarian: "VIZRAJZI MAGASSÁGJEGY 1895" ("hydrograph-

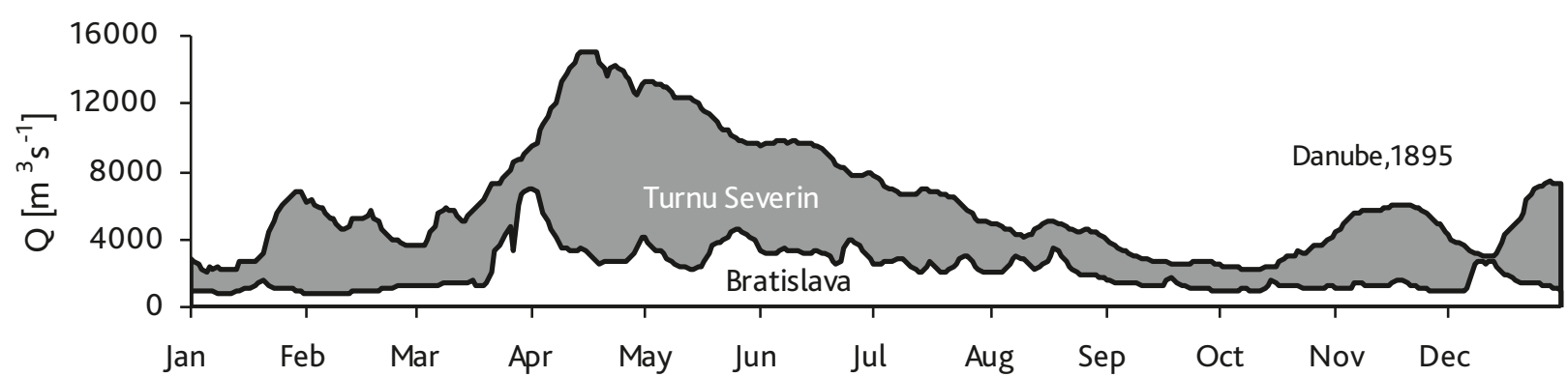

Figure 4. Mean daily discharge hydrographs from the Danube gauging stations of Bratislava and Turnu Severin/Orsova in 1895. 

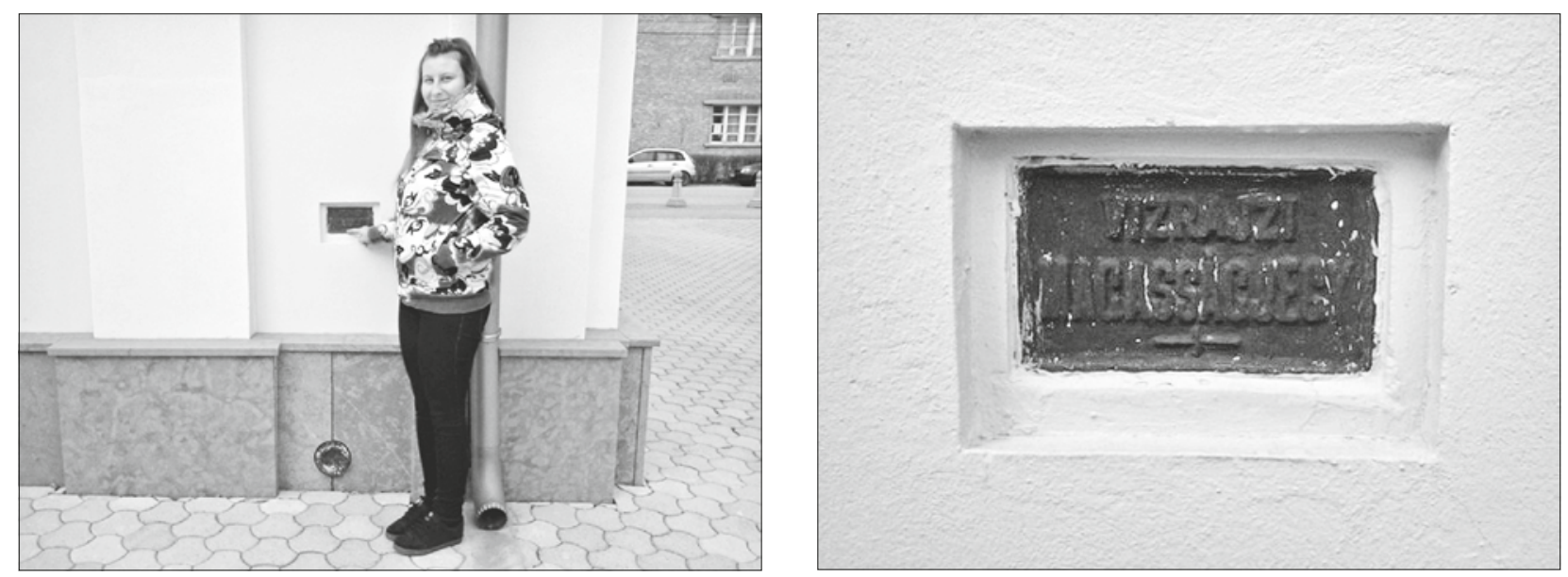

Figure 5. The 1895 flood mark in Komárom, St. Stephen`s church (photo by C.Dujsíková, 2013)
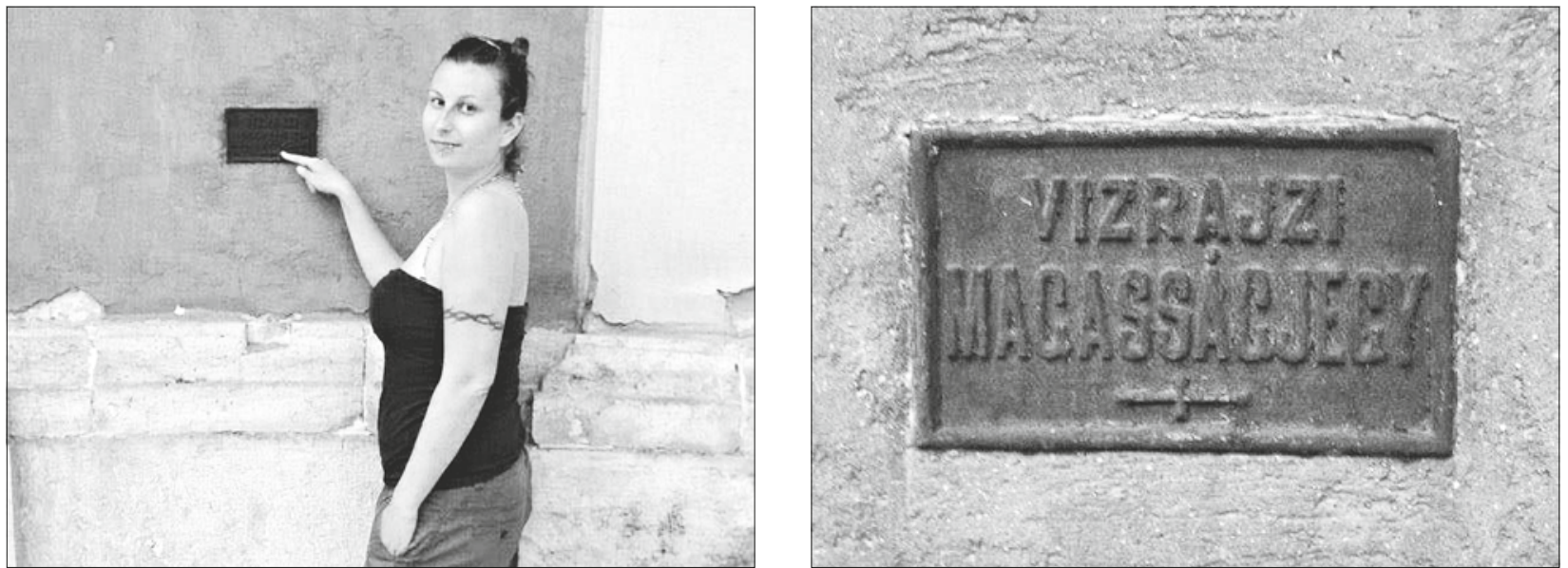

Figure 6. The 1895 flood mark in Szőny on a Roman Catholic church (photo by C.Dujsíková, 2013)

ic level mark 1895") and indicate the peak flood water level. From these marks it is possible to imagine the actual Danube water level's elevation in 1895. We also found one flood mark in 1895 from the Tisza River (Szeged in Hungary).

Another flood mark is from the Elbe catchment, and the date of culmination on 28 March 1895 is specified on the Elbe River in Pilnitz near Dresden.

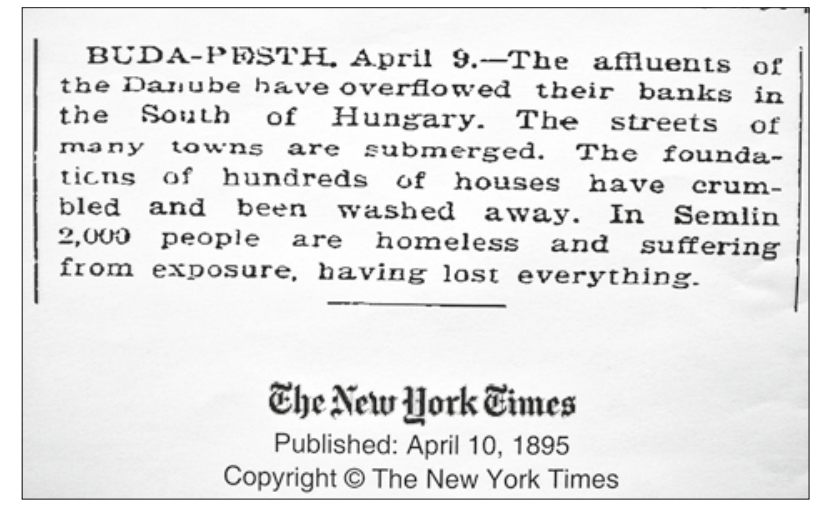

Figure 7. Report on the catastrophic 1895 Danube floods in southern Hungary in the New York Times, 10 April, 1895. (http://www.nytimes.com/)

\section{Information from the New York Times and Komáromi Lapok}

The New York Times only paid attention to reports about the 1895 Danube flooding in two short reports from their European correspondents. The first report was written by a Budapest correspondent on 9 April and printed in the newspaper on 10 April 1895 with the headline "Terrible Overflow in South Hungary” (see Figure 7). The sec-

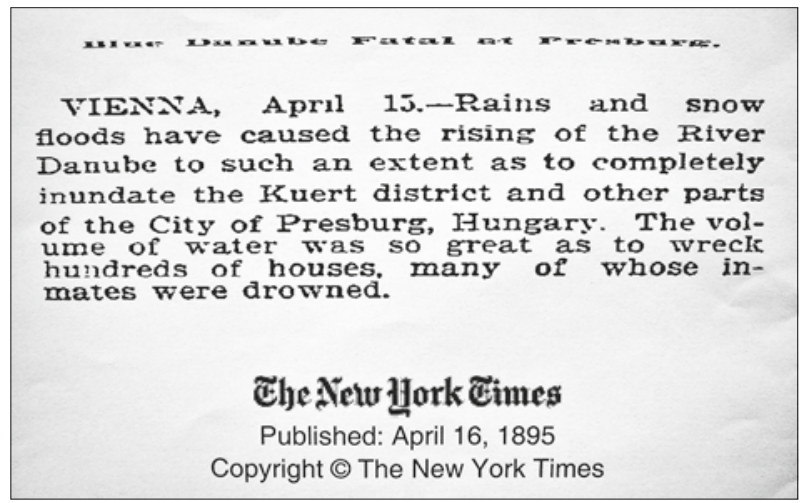

Figure 8. Report on the 1895 Danube flood at Presburg (Bratislava) in the New York Times, 16 April, 1895. (http://www.nytimes.com/) 
ond report, with the title "Blue Danube Fatal at Presburg", was published on 16 April 1895 by a Vienna correspondent (Figure 8). The headline of this report is not very precise, because the report mostly relates to Hungary and not only to Bratislava (at that time, Presburg).

At the beginning of April 1895, two reports appeared in the local weekly newspaper Komáromi Lapok about the Danube and Váh floods in several places in the vicinity of the town of Komárno (Slovakia and Hungary) (No. 14 from 6 April and No. 15 from 13 April 1895).

\section{Progress of the flood in 1895 on the Danube River and some of its tributaries based on the newspapers Wiener Zeitung and Preßburger Zeitung}

Here we are also furnishing information based on the study of materials regarding the historical floods on the Danube River and its tributaries in 1895 as reflected in the contemporary local press (Wiener Zeitung and Preßburger Zeitung) in the period from late February till the end of April 1895. From approximately 5 March until 24 April, reports appeared in the Wiener Zeitung and Preßburger Zeitung about floods at several places in Central Europe with the first of them arising on the tributaries of the Tisza River in Transylvania according to these newspapers.

The first wave of floods attacked the tributaries of the Tisza and the tributaries of the Danube in the regions of Transylvania and Vojvodina on 5 March, 1895 (the Mureş River in Arad (in western Romania), the Timiş River in Timişoara (in western Romania) (this river flows directly to the Danube near the Serbian town of Pančevo), the Crişul Alb River in ChisineuCris (in western Romania), the Moravica canal (runs directly into the Danube in Serbia) and the Brzava canal (a tributary of the river Timiş) near Zrenjanin (in Vojvodina in Serbia) (WZ 7 and 8 March). After this first wave of flooding of the tributaries of the Tisza and Danube rivers in this region, the situation stabilized for about two weeks.

In the period from late March till the beginning of April, as a result of continuous rain, flooding was documented in several areas in the Czech Republic, especially in southern Morava (the Morava River and its tributaries: the Dyje (Thaya), Svratka, Bečva, Jihlava, and Svitava), and some other rivers were rising in Bohemia. In several places the water left the inundation area (the Morava River near Olomouc, the Svratka River near Brno). Several dams collapsed at that time, and water flooded some areas of the surrounding fields, meadows and woods as well as the settlements and roads. Likewise, an area near the basin of the Morava River was underwater in Slovakia (PA, 23 March till PZ 6 April, WA 26 March till WA 1 April).
Over the entire Bavarian, Austrian and Slovak arms of the Danube, there was an increase in the water levels recorded (Straubing, Passau, Linz, Krems, Vienna, and Bratislava). Also, the Inn River in Scharding was constantly rising (PA and WZ 26 and 29 March). Snow in the mountains started to rapidly melt due to rain falling and thus caused a rapid increase in the water level of the Danube River and the tributaries in its upper part. The Wiener Zeitung reported on the flooding in Vienna on 27 and 28 March 1895, and the Pressburger Zeitung reported about the flooding in Bratislava in its evening edition from 1 April. Due to heavy rains the rivers Raab, Mur, Drava, Sava and the upper Tisza were rising (WA 1 April, PZ 2 April). The Danube was slightly rising below Bratislava, as was the entire Tisza (WA 1 April). The river Repcze near Sopron (in Hungary) broke its dams. Several thousand furlongs of fields were underwater. The area of Komárno-Komárom (in Slovakia and Hungary) was flooded. The Váh River near Komárno (in Slovakia) broke through its protective dam. Several houses collapsed. Fields and roads between Hurbanovo and Komárno (in Slovakia) and near Tata (in Hungary) were flooded. The Danube near Esztergom (in Hungary) was rising rapidly. The municipal garden in this city was completely underwater, and there was water standing in the surrounding fields as well. The Danube had already been rising for 5 days in Mohacs and had flooded two chalets situated on the island (WA 2 April). The Danube in Budapest had risen from 3 April to 4 April by approximately $14 \mathrm{~cm}$, and part of the city at the riverside remained underwater, for instance, the buildings and shops of the Danube Steamship Company. The groundwater started to rise in cellars in many houses in the inner city ( $\mathrm{PZ} 4$ April). According to information from $\mathrm{Bu}-$ charest, the Prut River and other smaller tributaries in Moldova overflowed their banks and caused floods (WZ 4 April). Near Mohacs, the water exceeded the highest water level, which had been reached in 1892, by $10 \mathrm{~cm}$ (WZ 6 April).

Other reports from the tributaries of the Tisza and Danube in the region of Transylvania and Vojvodina appeared in the Wiener Zeitung on 27 March, including reports about a significant increase in the level of the Tisza and its tributaries due to heavy rains. The river Tisza flooded several streets in the suburbs near the town of Chust (in western Ukraine). The Wiener Zeitung and Pressburger Zeitung from 27 March to 21 April brought daily notices about floods in various locations on the Tisza River and its individual tributaries: Someş, Criş, Mureş, the Bega canal, etc., and the tributaries of the Danube: Timiş and the Brzava and Moravica canals. For example, they provided information about flooding in the towns of Nyiregyhaza and Szegedin (in Hungary) on the Tisza Riv- 
er, in the town of Chisineu-Cris on the river Crisul Alb, in the towns of Deva, Târgu Mureş, Arad and Reghin (in western Romania) on the river Mureş, near the town of Dej (northwestern Romania) on the river Someş, and in the towns of Timişoara and Boka (in Vojvodina in Serbia) on the river Timiş. The information related to, for example, human casualties, losses of livestock, broken dams, collapsed houses, washedout railway tracks, flooded meadows and fields, etc. A fourth flood wave flowed down the rivers Timis and Bega (WZ 4 April). Due to the extremely heavy rain and constant snow melting, there was an imminent risk of flooding in Târgu Mureș. The residents of villages on the river Mureş left their houses, and many towns on this river were flooded. There was a great deal of panic (WZ and PZ 5 April). The Tisza in Szeged surpassed the until then known highest water level from 1888 by $17 \mathrm{~cm}$ (PZ 10 April). Early on the morning of 11 April, the dam near Cibakháza broke on the left bank of the Tisza River, thus flooding approximately 2,500 furlongs of the area (WZ 11 April). The village of Tiszatarján was completely flooded; a lot of houses had collapsed in Tiszakesz, which was mostly underwater; Tiszakürt was in great danger, and its inhabitants were trying to escape (PA 16 April).

The floods also affected a large part of the basins of the rivers Drava and Sava. For example, the newspapers were reporting about the floods in Zagreb, where the Sava suddenly rose and flooded the suburbs, where the water was one meter deep in the dwelling houses. Also affected were the narrow streets of the lower city of Zagreb. The area looked like a large lake. Only the roofs of houses could be seen due to the water in the villages on the banks of the Sava. There had not been such a flood in 29 years (PZ and WZ 28 March). Due to the rapid rise of the Sava and Danube, the evacuation of citizens was ordered from Belgrade from houses in the lower parts of the city. The Danube and Sava suburbs were partly underwater (WZ 6 and 7 April). The newspapers reported on the flooding in Bosnia and Herzegovina; Bosanski Brod (on the Sava River) was completely flooded. Part of the residents stayed in Slavonia, and part escaped to a hill. The whole area reminded spectators of the sea (PA 8 April).

The water level on the Danube in Zemun (now part of Belgrade) reached $7^{1 / 2}$ meters on midday, 8 April. Due to the significant inflow from the Sava and Drina rivers, there was a risk of a further increase. The transshipment point of the Hungarian State Railways in Zemun was flooded by water to a height of more than one meter. In an even worse situation, the neighboring former Hungarian villages of Barcsa (now Borča in Serbia) and Ostcsa (Ovča in Serbia) were completely flooded. With great efforts and with the help of ships of the Hungarian State Railways, approximate- ly 2,00o residents of these villages were evacuated to Zemun and to Pančevo (in Serbia). Rain had been falling since the early morning of 9 April, so the flood concerns were becoming greater. The Hungarian and Croatian riverside areas of the Danube and Sava had flooded more than the Serbian bank. The residents escaped to Serbia, where the bank was located at a higher altitude (WA 9 April). The Danube was rising rapidly from Bogojeva (in Vojvodina, Serbia) downward, especially at its confluence with the Sava ( $\mathrm{WZ}_{10}$ April). Conditions in the area of Torontal gave rise to a high level of concern. The village of Boka (currently in Vojvodina, Serbia) on the river Tamiš was flooded; more than 200 houses collapsed, and 700 people were left homeless (WA 9 April). The passenger and freight railway traffic from Belgrade to Smederevo (in Serbia) was stopped due to the flooding of the tracks (WZ and PA 11 April).

The Danube in Zemun had risen on 11 April by approximately $15 \mathrm{~cm}$ since the previous day. There was water standing in the streets of Zemun up to a height of $1.5 \mathrm{~m}$. The residents were greatly concerned as the rivers Sava and Drina were rapidly rising again. In addition to the villages of Bortcsa and Ostcsa, there were also other flooded villages between Zemun and Pančevo. Steamboats and towboats were helping to evacuate the residents (WA 11 April). According to a report from Belgrade, significant damage to fields, streets, and bridges was caused not only by the Sava and Danube, but also by the rivers Morava and Drina in Serbia (WA 11 April). A significant increase in the water level was reported below the Novi Sad (WZ 12 April). The river Sava flooded the salt and oil reservoirs of a monopoly enterprise in Belgrade ( $\mathrm{PZ} 13$ April).

As reported from Bucharest on 13 April, the Danube's level increased considerably on the Romanian territory and flooded some areas, but, without any major damage thus far. The water level raised by approximately 5.6 meters in the towns of Giurgiu and Orsova (WA 13 April, PZ 14 April). The Danube island fortress of Ada-Kalé was completely flooded. Turks escaped to the fortress, which was strengthened by embankments. There were great shortages of necessities and the risk of starvation. The old Turkish mosque was underwater and close to collapsing. Villages on the Serbian bank were completely flooded. Residents escaped to the inlands of Serbia (WZ and PZ 20 April). The Danube at Pančevo reached its highest recorded water level, surpassing the record set in 1888. There were 23 buildings flooded thus far. Vidin in Bulgaria reported that on 17 April, the Danube rose by approximately $10 \mathrm{~cm}$ (WZ 20 April). The Danube and most of the other rivers on the Romanian territory were rising and causing partial flooding. There were fields 

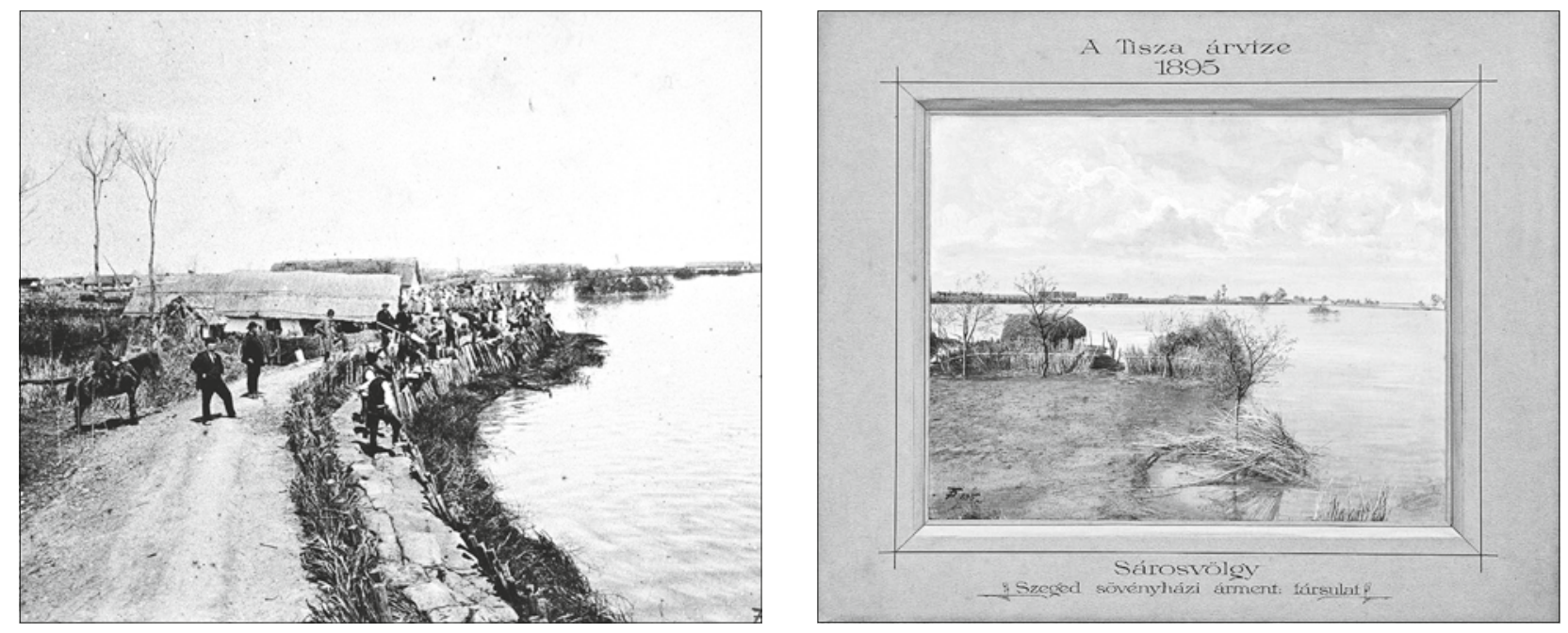

Figure 9. The Tisza flood (April 1895)

(the photos on the left and right are taken from the archives of the Danube Museum in Esztergom, Hungary)

flooded near Galati (in Romania), and in multiple locations transportation could only be carried out by boats (WZ 21 April). The Danube in Romania continued to rise. In Giurgiu, the dam and port were under a risk of flooding. In the town of Braila, brick plants and low parts of the town were flooded. Four people and a large number of cattle drowned in the village of Cocargeana close to Calarasch. Also, the village of Chirnogi was affected by the flood (WA 24 April).

The March/April 1895 floods also affected some other rivers in Central Europe, such as the Vltava (Prague), Elbe (Dresden, Hamburg vicinity), Dniester and the river Bug.

\section{Other historical sources (chronicles, books and photos)}

The occurrence of the 1895 flooding on the Danube River was confirmed by records from the local chronicles of the following villages: Konnigsbrunn am Wagram in Austria, and Medvedov and Obid in Slovakia.

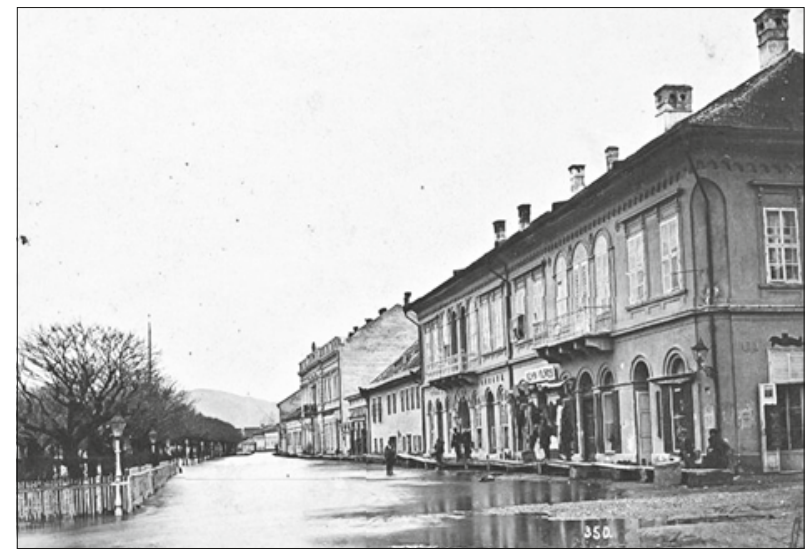

Some mentions of the flooding in 1895 are recorded in the yearbook of meteorological observations of 1895 (JCME, 1898) (e.g., Přerov on the Bečva River in the Czech Republic) and in a book "Study of selected natural extremes and their impacts in Moravia and Silesia" (Brázdil, et al., 2007) (e.g., the Dyje and Svratka rivers in the Czech Republic). Contemporary photos suitably illustrate the flooding events. During the flood of 1895, water overflowed several inundation areas of the Tisza River (Figure 9), and the streets of Orsova were underwater (Figure 10).

\section{Conclusion}

Information from the Wiener Zeitung, Preßburger Zeitung, and other historical sources helped us reconstruct the history of the flooding, record the consequences and the territorial radius itself as well as clarified the causes of the origin of the flooding in March and April 1895 of the Danube and its tributaries. Analysed records from the newspapers show relatively

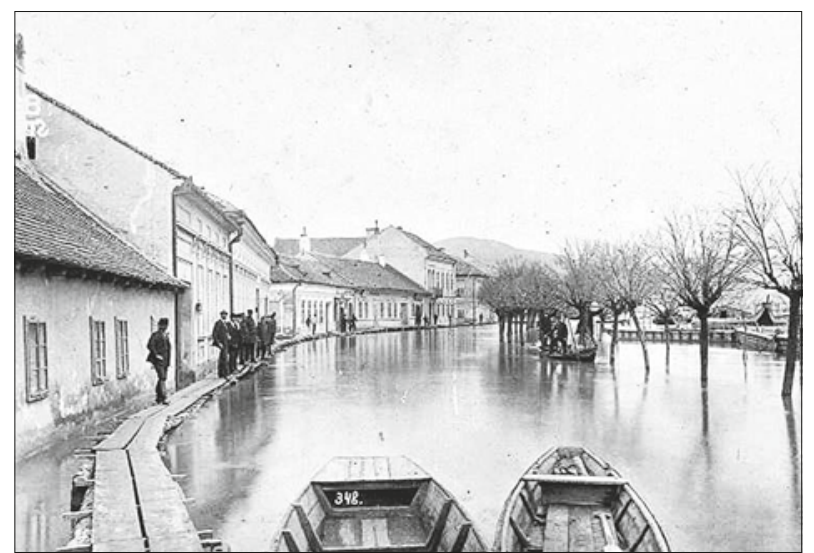

Figure 10. The Danube flood at Orsova (April 1895)

(photos on the left and right are taken from reference: http://orsova.xhost.ro/). 
large territorial impact of the flooding in March and April 1895, which affected not only the Danube and its tributaries, but also some other neighboring basins. The catastrophic consequences of the flooding were especially reported from the lower parts of the Danube River (from its confluence with the river Drava up to the mouth of the Black Sea) and the tributaries of the Tisza and Sava rivers.

It was necessary for the Danube countries to closely cooperate. In their national archives, they possess many valuable documents that help in evaluating the Danube flood regime in the entire Danube River catchment area.

\section{Acknowledgements}

This publication is the result of the implementation of the project ITMS 26240120004 Centre of excellence for integrated flood protection of land supported by the Research \& Development Operational Programme funded by the ERDF.

This work was supported by the Slovak Research and Development Agency under Contract No. APVV-oo1510 and No. APVV-0303-11.

\section{References}

Bel, M. 1735. Notitia Hvngariae Novae Historico-Geographica: Divisa In Partes Qvatvor, Qvarvm Prima, Hvngariam Cis-Danvbianam; Altera, Trans-Danubianam; Tertia, Cis-Tibiscanam; Qvarta, Trans-Tibiscanam: Vniuersim XLVIII. Tomus Primus.

Blaškovičová, L., Danáčová, Z., Lovásová, L., Šimor, V., Škoda, P. 2013. The development of selected hydrological characteristics of the Danube in Bratislava. Expert seminar on the occasion of Danube Day. http://www.shmu.sk/File/ExtraFiles/ODBORNE_ AKTUALITY/files/hydro/Vyvoj_H_charakteristik_ na_Dunaji_v_BA.pdf.SHMI, pp. 22-31 (in Slovak).

Brázdil, R., Kundzewicz, Z.W. 2006. Historical hydrology - Editorial. In: Hydrological Sciences Journal. 51 (5), 733-738.

Brázdil, R., Kirchner, K., Březina, L., Dobrovolný, P., Dubrovský, M., Halásová, O., Hostýnek, J., Chromá, K., Janderková, J., Kaláb, Z., Keprtová, K., Kotyza, O., Krejčí, O., Kunc, J., Lacina, J., Lepka, Z., Létal, A., Macková, J., Máčka, Z., Mulíček, O., Roštínský, P., Řehánek, T., Seidenglanz, D., Semerádová, D., Sokol, Z., Soukalová, E., Štekl, J., Trnka, M., Valášek, H., Věžník, A., Voženílek, V., Žalud, Z. 2007. Vybrané přírodní extrémy a jejich dopady na Moravě a ve Slezsku (Study of selected natural extremes and their impacts in Moravia and Silesia). Masarykova universita, Český hydrometeorologický ústav, Ústav geoniky Akademie věd ČR, v.v.i., Brno, Praha, Ostrava, 432 pp. (in Czech with English summary)

Brázdil, R., Kundzewicz, Z.W., Benito, G., Demarée, G., Macdonalds, N., Roald, L.A. 2012. Historical floods in Europe in the past millennium. In: Kundzewicz, Z.W. (ed.) (2012): Changes in flood risk in Europe. IAHS Special Publication 10, IAHS Press, Wallingford, 121-166 pp.

Elleder, L. 2010. Reconstruction of the 1784 flood hydrograph for the Vltava River in Prague, Czech Republic. Global and Planetary Change 70, 117-124.

Elleder, L., Herget, J., Roggenkamp, T., Nießen, A. 2013. Historic floods in the city of Prague - a reconstruction of peak discharges for 1481-1825 based on documentary sources. Hydrology Research 44 (2), 202-214.

JCME 1898. Jahrbücher der K.K. Central-anstalt für meteorology und erdmagnetismus. Officielle publication. Jahrgang 1895. Wien, 128 pp.+191 pp.+40 pp.

Kiss, A. 2009. Historical climatology in Hungary: role of documentary evidence in the study of past climates and hydrometeorological extremes. Időjárás 113 (4), 315-339.

Kiss, A. 2011. Floods and long-term water-level changes in medieval Hungary. Doctoral dissertation. Central European University Budapest, Hungary, $323 \mathrm{pp}$.

Kresser, W. 1957. Die Hochwässer der Donau (The flood waters of the Danube). Springer Verlag, Wien, $95 \mathrm{pp}$.

Marušiak, O., Pekár, J. 2014. Identification of longterm periods of the discharge time series variability by the CEEMDAN method. Acta Hydrologica Slovaca 15 (1), 151-16o (in Slovak).

Melo, M., Bernáthová, D. 2013. Historical floods in the Slaná river basin since the end of the $18^{\text {th }}$ century till the beginning of the $20^{\text {th }}$ century. Acta Hydrologica Slovaca, 14 (2), 291-298 (in Slovak).

Munzar, J., Ondráček, S. 2010. Precipitation extremes and disastrous floods in Central Europe in July 1897. In: Przybylak, R. et al. (eds.) 2010. The Polish Climate in the European Context. An Historical Overview. Springer, Dordrecht, 389-396 pp.

Neweklowsky, E. 1955. Die Donau bei Linz und ihre Regelung (The Danube at Linz and its control). Naturkundliches Jahrbuch der Stadt Linz 1: (1955): download unter http://www.landesmuseum.at/datenbanken/digilit/?litnr=24580 171-226 (in German).

Pekárová, P., Halmová, D., Bačová Mitková, V., Miklánek, P., Pekár, J., Škoda, P. 2013. Historic flood marks and flood frequency analysis of the Danube River at Bratislava, Slovakia. Journal of Hydrology and Hydromechanics 61 (4), 326-333.

Pekárová, P., Miklánek, P., Pekár, J., Melo, M. 2012. The Danube flood in year 1895. Part II.: In instru- 
mental discharge data. Acta Hydrologica Slovaca 13 (2), 280-288 (in Slovak).

Pekárová, P., Onderka, M., Pekár, J., Miklánek, P., Halmová, D., Škoda, P., Bačová Mitková, V. 2008. Hydrologic Scenarios for the Danube River at Bratislava. Ostrava, KEY Publishing, http://pavla.pekarova. sk/monografie, $159 \mathrm{pp}$.

Pišút, P. 2011. The 1787 flood of the River Danube in Bratislava, Geografický časopis 63 (1), 87-109 (in Slovak).

Rohr, C. 2005. The Danube floods and their human response and perception (14th to 17 th C). History of Meteorology (2) 71-86.
Stankoviansky, M., Pišút, P. 2011. Geomorphic response to the little ice age in Slovakia. Geographia Polonica 84 (1), 127-146.

Resource documents on flood risk from the archives of the Danube Museum in Esztergom (Hungary); library of the Danube Region Museum in Komárno (Slovakia) and archives of the Austrian National Library in Vienna (Austria).

http://orsova.xhost.ro/

http://www.nytimes.com/ 